\title{
Prevalence and Atopy Association of Mycoplasma Pneumoniae and Chlamydia Pneumoniae Infections in Infants with Recurrent Wheezing
}

'Department of Child Health and Diseases, Eskișehir Osmangazi University,

Faculty of Medicine, Eskisehir, Turkey

${ }^{2}$ Department of Microbiology, Eskisehir Osmangazi University, Faculty of Medicine, Eskisehir, Turkey

${ }^{3}$ Department of Pediatric Immunology and Allergy Diseases, Eskişehir Osmangazi University, Faculty of Medicine, Eskisehir Turkey

Correspondence:

Gürkan BOZAN

Department of Child Health and Diseases, Eskișehir Osmangazi University, Faculty of Medicine, Eskisehir, Turkey

\section{Abstract}

The most common cause in the etiology of wheezing is respiratory tract infections. Viruses (in especially RSV), Chlamydia Pneumoniae and Mycoplasma Pneumoniae bacteria can cause transient airway hypersensitivity and wheezing by causing tissue damage and inflammation when they reach the lower respiratory tract. The association has been demonstrated and discussed between these two atypical bacteria and asthma. By setting major and minor parameters for predicting asthma risk, the asthma predictive index (API) was developed in children with excessive wheezing. This study was planned to examine the relationship of atopy and atypical bacterial infections in infants with persistent wheezing. Thirty-two females and fifty-eight males children under 2 years of age were included in the study. Fifty-six cases (62.2\%) were positive for API and thirty-four cases (37.8\%) were negative. The presence of infection was investigated by enzyme-linked immunosorbent assay (ELISA) and polymerase chain reaction (PCR) method. It was found that both infections were substantially more serious in the second year than in the first year of life. However no statistically meaningful outcome was obtained, when comparing the presence of both pathogens and API positivity. Regardless of the API, the existence of bacterial agents was found to be statistically meaningful, especially in the range of 1-2 years, when subgroup analysis was performed in children with wheezing under the age of 2 years. It is appropriate to keep in mind the existence of these two bacteria in wheezy children. In the second year of life, both infection agents also showed a statistically significant increase and found that these patients could develop persistent wheezing.

Keywords: Wheezing, Mycoplasma pneumoniae, Chlamydia pneumoniae, API (Asthma Predictive Index).

\section{Özet}

Hışltılı çocuklarda; etyolojide en sık neden solunum yolu enfeksiyonlarıdır. Solunum yolu virüsleri (özellikle RSV) ve Chlamydia Pneumoniae ve Mycoplasma Pneumoniae gibi bazı bakteriler insanlarda alt solunum yollarına ulastıklarında doku hasarı ve enflamasyonu başlatarak geçici hava yolu aşırı duyarlılığına ve hışıltıya neden olabilmektedir. Bu iki atipik bakterinin astım ile ilişkisi olduğu gösterilmiş ve niteliği sıklıkla tartışma konusu olmuştur. Astım riskini tahmin etmek için majör ve minör parametreler belirlenerek, tekrarlayan hışıltılı çocuklarda astım prediktif indeksi (API) geliştirilmiş ve tekrarlayan hışıltılı infantlarda atopi ve atipik bakteriyel enfeksiyonların iliş̧kisini incelemek için bu çalışma planlanmıştır. Tekrarlayan hışıltısı olan süt çocuklarında atopi ile atipik bakteri enfeksiyonlarının ilişkisini araştırmak amacıyla; 2 yaş altı kriterlerimize uygun elli sekizi erkek otuzikisi kız hasta çalışmaya alındı. Yapılan değerlendirmelerin sonucunda elli altı hastada (\%62.2) API pozitif, otuz dört hasta da (\%37.8) negatif olarak değerlendirildi. Hastalardan alınan kan örneklerinde M. Pneumoniae ve C. Pneumoniae için ELISA ve PCR yöntemi ile enfeksiyon varlığı araștırıldı. Her iki enfeksiyonun incelenmesi sonucunda hayatın ilk yılına göre, 2. yllında (12-24 ay arası) anlamlı derecede daha fazla enfeksiyon saptandı. Ancak hastaların her iki enfeksiyonun varlığı ve API pozitifliği yönünden karşılaştırması yapıldığında istatistiksel olarak herhangi bir anlamlı sonuca ulaşılamadı. API bağımsız olarak 0-2 yaş grubundaki hışıltılı çocuklarda subgrup analizi yapıldığında özellikle 1-2 yaş aralığında bu etkenlerin varlı̆̆ istatistiksel olarak anlamlı saptandı. Bu gruptaki hışıltılı çocuklarda; bu iki mikroorganizmanın varlığı akılda tutulmalıdır. Her iki enfeksiyon ajanı için de hayatın 2. yılında istatistiksel olarak anlamlı bir artış olduğunu ve bu hastaların tekrarlayan hışıltı atakları geliştirebileceğini saptadık.

Anahtar Kelimeler: Hışıltı, Mycoplasma Pneumoniae, Chlamydia Pneumoniae, API (Astım Prediktif İndeks) 


\section{Introduction}

Wheezing is a nonspecific examination of the airflow through the narrowed airways, which is the result from turbulent flow in the bronchial walls and is heard at the breathing expiratory phase (1). More than 30\% of children younger than one year of age and at least one $50 \%$ of children younger than six years of age experiencing at least one wheeze. It is important to be able to decide whether a wheezing child is a sign of respiratory tract infection or a symptom of asthma. (2). The Tucson Children's Respiratory Study first defines an index that predicts the risk of asthma in children with at least one wheeze or chronic wheeze. Then, due to new risk factors, Expert Panel Report 3 (EPR3) was updated in 2007 and the 'modified asthma prediction index' was created. (2,3). The asthma predictive index (API) was developed in children with at least one episode of wheezing or recurrent wheezing by adjusting major and minor parameters to determine the risk of asthma. Major criteria; history of mother and father asthma, presence of atopic dermatitis, presence of sensitization of the inhalant allergen and minor criteria; eosinophilia, wheezing without cold and food allergy. The predictive index of asthma is considered positive in the case of at least one wheeze with one of the major criteria, or two of the minor criteria with wheeze without the major criteria, $(4,5)$. Infections are the main cause of recurrent wheezing episodes in patients without asthma. RSV and rhinovirus are at the forefront of infectious agents and Mycoplasma Pneumoniae and Chlamydia Pneumoniae may be responsible for triggering the development of wheezing in atopic patients. $\quad(4,5) . \quad 5-10 \%$ of childhood pneumonia is responsible for by Chlamydia Pneumoniae. Upper respiratory tract symptoms can be self-limiting or can be transformed into prolonged cough with lower respiratory tract infection. (6). M. Pneumoniae infection is one of the potential causes, especially in young children and infants with first wheezing attack and persistent wheezing may be developed in atopic children with this infection. It is also known that this agent is an important infectious agent in asthmatic children at the start of an attack or in a circumstance in which the subsequent attacks become severe and require hospital admission (7). Viruses, Chlamydia Pneumonia and Mycoplasma Pneumoniae, as they reach the lower respiratory tract in humans, cause tissue damage and inflammation, inducing transient airway hyperresponsiveness for up to 6-7 weeks (8). Inflammation in bronchioles causes airway obstruction and airway hyperresponsiveness in many ways. Impairment of siliceous epithelial functions and alteration of mucus composition contributes to the development of airway obstruction associated with virus and Chlamydia pneumoniae and Mycoplasma pneumoniae (9).

\section{Objective}

The relationship of these two atypical bacteria to the development of asthma has been investigated in several studies over the past few years. In pediatric patient population, we did not notice a clinical trial challenging the correlation of these infection factors with the Asthma Predictive Index. In our study; in 90 patients between 1-24 months who had recurrent wheezing we found asthma predictive index through history and laboratory tests. Mycoplasma pneumoniae and Chlamydia pneumoniae were detected by PCR and ELISA methods. We aimed to determine whether atypical factors play a role in infants with wheezing.

\section{Materials and Methods}

Between January 2014 and January 2015, aged 1-24 months 90 infants with persistent wheeze were enrolled in the study at Eskisehir Osmangazi University. Exclusion criteria; metabolic disease, prematurity, bronchopulmonary dysplasia, congenital heart disease, and airway anomalies. Patients under the age of 2 years who had at least 3 wheezes were selected. Informed consent form was obtained by interviewing the families of the infants who met the research criteria and the study protocol was approved by the Ethics Committee of Eskişehir Osmangazi University dated 09.06.2014 and numbered $80558721 / 156$. The appropriation for the study budget was obtained from the Scientific Research Project Commission of Eskişehir 
Osmangazi University with the application number 2014-294. A detailed history of acute disease was recorded from parents, physical findings of wheezy infants, laboratory tests, inhalants and food skin tests were analyzed. Participant was asked about the presence of typical rashes for atopic dermatitis and nasal signs for allergic rhinitis. The family history of asthma, wheezing episodes, coughing qualities and the association with effort has been questioned. Blood samples were collected for laboratory studies; Total blood count (\% eosinophil), Total IgE level, phadiatop (allergy screening test) inhalant and phadiatop food were studied. Patients were scheduled to undergo skin testing with prick (puncture) method. Asthma Predictive Indexes (API) of patients were detected in all these data.

Patient blood samples for Mycoplasma Pneumoniae PCR and Clamidia Pneumoniae PCR analysis, Qiagen Biorobot M48 instrument and Euroclone PCR kit were used. The Serion brand Virion ELISA kit was then used with Mindray MR-96A by Diagen Company for the same blood samples as Mycoplasma Pneumoniae IgM and Chlamidia Pneumoniae IgM.

Statistical analysis of the data was performed using SPSS (version 18.0 for Windows, Chicago, IL) statistical program. For the definitions, frequency analysis test was used, Chi-square analysis test was used for comparison; A value of $\mathrm{p}$ below 0.05 was considered statistically significant.

\section{Results}

There were ninety infants with recurrent wheeze between 1-24 months were enrolled in the study. Fifty-eight $(58.6 \%)$ were males and thirty-two (35.6\%) were females. Age distributions ranged from 1-6 months in five patients $(5.6 \%)$ and in 7-12 months in thirtyfour patients (37\% 8), 13-18 months in twenty patients $(22.2 \%)$ and 19-24 months in thirtyone patients $(34.4 \%)$. Patients recorded that thirty-one $(34.4 \%)$ were associated with asthma, nine $(10 \%)$ with atopic dermatitis, fourty-seven $(52.2 \%)$ with respiratory infections, and sixty-two (68.9 \%) with allergic rhinitis (Table 1 ) In wheezing children; APIs were calculated and recorded by evaluating family history of asthma and atopic dermatitis, inhalant and food skin tests, total IgE and eosinophil levels. Fifty-six patients $(62.2 \%)$ were positive for API and thirty-four patients $(37.8 \%)$ were negative for API (Table 2). M. Pneumoniae IgM was detected in eight patients $(8.9 \%), C$. Pneumoniae IgM was positive in fourteen patients $(15.6 \%)$, and no positive results were found for $M$. Pneumoniae PCR and $C$. Pneumoniae PCR. As a result of age-related analysis in patients with $M$. Pneumoniae IgM positivity, statistically significant $(\mathrm{p}<0.001)$ was found in the second year (12-24 months) and not in the first year of life. Patients were also shown to be statistically significant $(\mathrm{p}=$ 0.001 ) in terms of $C$. Pneumoniae IgM positivity in the second year (12-24 months) (Table 3) Statistically significant results were not obtained as patients were compared with M. Pneumoniae PCR and C. Pneumoniae IgM positivity and Asthma Predictive Index positivity (Table 4).

Table 1. Demographic characteristics of patients

\begin{tabular}{|c|c|}
\hline Demographic characteristics & $\begin{array}{c}\text { Patients } \\
\mathbf{n}=90\end{array}$ \\
\hline \multicolumn{2}{|l|}{ Sex } \\
\hline $\begin{array}{l}\text { Female } \\
\text { Male }\end{array}$ & $\begin{array}{l}32(\% 35.6) \\
58(\% 64.4)\end{array}$ \\
\hline \multicolumn{2}{|l|}{ Age } \\
\hline 1-6 months & $5(\% 5.6)$ \\
\hline 7-12 months & $34(\% 37.8)$ \\
\hline 13-18 months & $20(\% 22.2)$ \\
\hline 19-24 months & $31(\% 34.4)$ \\
\hline
\end{tabular}




\begin{tabular}{lc}
\hline Family asthma story & $\mathrm{n}=90$ \\
Yes & $31(\% 34.4)$ \\
No & $59(\% 65.6)$ \\
Upper respiratory tract infection & \\
Yes & $\mathrm{n}=73$ \\
No & $47(\% 52.2)$ \\
& $26(\% 28.8)$ \\
Atopic dermatitis & $\mathrm{n}=68$ \\
Yes & $9(\% 10.1)$ \\
No & $59(\% 65.5)$ \\
Allergic rhinitis & $\mathrm{n}=90$ \\
Yes & $62(\% 68.9)$ \\
No & $28(\% 31.1)$ \\
\hline
\end{tabular}

Table 2. Demographic characteristics of patients and comparison with API (+) and API (-)

\begin{tabular}{lccl}
\hline & $\begin{array}{c}\text { API (+) } \\
\mathbf{n}=\mathbf{5 6}\end{array}$ & $\begin{array}{c}\text { API (-) } \\
\mathbf{n = 3 4}\end{array}$ & P \\
\hline $\begin{array}{l}\text { Sex } \\
\text { Female }\end{array}$ & $23(\% 41)$ & $25(\% 73)$ & $>0.05$ \\
$\quad$ Men & $33(\% 59)$ & $9(\% 27)$ & \\
Age & & & \\
$\quad \mathbf{1 - 6}$ months & $3(\% 5)$ & $2(\% 6)$ & \\
$\mathbf{7 - 1 2}$ months & $22(\% 39)$ & $12(\% 35)$ & $>0.05$ \\
$\mathbf{1 3 - 1 8}$ months & $13(\% 23)$ & $7(\% 20)$ & \\
$\mathbf{1 9 - 2 4}$ months & $18(\% 32)$ & $13(\% 39)$ & \\
& & & \\
\hline
\end{tabular}

Table 3. Comparison of Mycoplasma Pneumoniae and Chlamydia pneumoniae IgM (+) and IgM (-) in patients compared to 6-month periods

\begin{tabular}{|c|c|c|c|c|c|}
\hline & $\begin{array}{l}\text { Mycoplasma } \\
\text { Pneumoniae IgM + }\end{array}$ & $\begin{array}{c}\text { Mycoplasma } \\
\text { Pneumoniae IgM - }\end{array}$ & $\begin{array}{c}\text { Chlamydia } \\
\text { Pneumoniae IgM } \\
+\end{array}$ & $\begin{array}{c}\text { Chlamydia } \\
\text { Pneumoniae IgM - }\end{array}$ & $\mathbf{P}$ \\
\hline 1-6 months & 0 & $5(\% 100)$ & 0 & $5(\% 100)$ & \multirow{4}{*}{$<0.001$} \\
\hline 7-12 months & 0 & $34(\% 100)$ & 0 & $34(\% 100)$ & \\
\hline 13-18 months & $2(\% 10)$ & $18(\% 90)$ & $5(\% 25)$ & $15(\% 75)$ & \\
\hline 19-24 months & $6(\% 19.3)$ & $25(\% 80.7)$ & $9(\% 29)$ & $22(\% 71)$ & \\
\hline
\end{tabular}

Table 4. Comparison of Mycoplasma Pneumonia and Chlamydia Pneumoniae IgM (+) and IgM (-) and Asthma Predictive Index (+) and (-) in Patients

\begin{tabular}{cccccc}
\hline & $\begin{array}{c}\text { Chlamydia } \\
\text { Pneumoniae } \\
\text { IgM+ }\end{array}$ & $\begin{array}{c}\text { Chlamydia } \\
\text { Pneumoniae IgM } \\
-\end{array}$ & $\begin{array}{c}\text { Mycoplasma } \\
\text { Pneumoniae } \\
\text { IgM }+\end{array}$ & $\begin{array}{c}\text { Mycoplasma } \\
\text { Pneumoniae IgM } \\
-\end{array}$ & P \\
\hline $\begin{array}{c}\text { API } \\
\text { Pozitive }\end{array}$ & $8(\% 14.2)$ & $48(\% 85.8)$ & $3(\% 5.4)$ & $53(\% 94.6)$ & $>0.05$ \\
API negative & $6(\% 17.6)$ & $28(\% 82.4)$ & $5(\% 14.8)$ & $29(\% 85.2)$ \\
\hline
\end{tabular}




\section{Discussion}

In our research, we tried to determine the prevalence of Mycoplasma Pneumoniae and Chlamydia Pneumoniae and the relationship to the predictive asthma index in children with recurrent wheezing. The presence of $M$. Pneumoniae and C. Pneumoniae infections did not statistically establish the significant effect which we expected to have on a good predictor of asthma development API in our study group. However, in 0-2 age group when subgroup analysis was performed on wheeze children independently of API, Mycoplasma Pneumoniae and Chlamydia Pneumoniae prevalence were found to be statistically significant especially in 1-2 years range.

The most frequent cause of wheezing is respiratory infections.Respiratory viruses, Chlamydia Pneumoniae and Mycoplasma Pneumoniae can induce tissue damage and inflammation causing transient airway hypersensitivity and wheezing(8). The effect of infections on the pathogenesis of asthma is still unclear. Epidemiological and experimental animal studies have reported that viruses and two atypical bacteria, Chlamydia Pneumoniae and Mycoplasma Pneumoniae, may lead to possible persistent infections and may play a role in asthma pathogenesis $(10,11)$.

Teoh et al.(12) in a PCR analysis performed by $M$. and $C$. Pneumoniae infections have been found to cause acute asthma in the presence of atopy, as well as viruses in small children. A important correlation between asthma and elevated Chlamidya Pneumoniae specific IgA titers has been reported in a study of patients diagnosed with persistent infection and asthma. This has been interpreted as a chronic infection that constitutes a sustained stimulus, which in turn affects inflammation through tissue damage and restructuring, leading to asthma severity(13).

In our work; we did not find statistically significant contribution of $M$. Pneumoniae and C. Pneumoniae infections, which are one of the aims of our study, to API positivity.

Emre et al.(14) in a study asthmatic children reported that $C$. pneumoniae infection may cause asthma exacerbations 'However, in a study conducted by Cunningham et al.(15) with PCR method in wheezy children; found no association between asthma exacerbation and Chlamydia pneumoniae infection. Several studies have reported a correlation between $C$. pneumoniae infection and childhood asthma exacerbation(16). However, no correlation was found in a controlled clinical trial in which serology was used between $C$. pneumoniae infection and acute asthma $\operatorname{attack}(17)$.

Smith-Norowitz et al. have shown that Chlamydia Pneumoniae infection, identified by ELISA, induces an allergic response in peripheral blood mononuclear cells, raising the IgE and Th2 cell response likes asthma exacerbation (18). The same group showed that Chlamydia Pneumoniae identified by ELISA and PCR, plays a role in pathogenesis of asthma by increasing IFN- $\gamma$ responses in peripheral mononuclear cells in allergic asthmatic children, even in the absence of active infection(19).

Esposito et al.(20) has reported that $M$. Pneumoniae was more prevalent in the patient group than controls and was strongly associated with recurrent wheeze episodes in a study using serology and PCR in children. Biscardi et al.(21); in asthmatic patients reported that acute $M$. Pneumoniae infection predisposes to the development of asthma and is a triggering factor for asthma attacks. However, Bebear et al.(22); in a study investigating the role of $M$. Pneumoniae and C. Pneumoniae in the pathogenesis of acute asthma; did not reach meaningful evidence that they played a direct role in the pathogenesis and exacerbations.

The differences between the results of the studies were tried to be explained by the diagnostic methods used. Serological tests have been used in most studies. The limitation to serological diagnosis is the antibodies to $M$. Pneumoniae can occur due to other infections with Mycoplasma and cross-reacting antigens such as Streptococcus. False positives may affect the outcome of the study. The 
disadvantage of culture studies is the long time and strength of reproduction (23).

Hardy et al.(24) showed that M. Pneumoniae infection of asthma Predisposed individuals is accompanied by certain pathophysiological changes that reduce lung function in the same way as asthma, which in turn leads to the progression or exacerbation of asthma. Another fair point from the study is the evidence that treatment with successful antibiotics in asthmatic patients with Mycoplasma Pneumoniae infection has increased lung function, and these results mean that infection may play a role in chronic asthma.

Jeong et al.(25) found that the levels of vascular endothelial-

derived growth factor (VEGF) and IL-5 cytokines increased in M. Pneumoniae infection identified by ELISA in atopic children and increased sensitivity of the airways by proinflammatory mechanisms, suggesting that the allergic disease was exacerbated. Kim et al.(26) observed that even after two months of Mycoplasma Pneumoniae infection, eosinophil-mediated hyperreactivity continued due to elevated levels of serum IL-5 and ECP in atopic infants.

However, Wood et al.(27) found that $M$ Pneumoniae persisted longer in clinically asthmatic children in their study using ELISA and PCR, but did not show statistical significance for asthma worsening and exacerbation frequency.

While there is evidence of correlation between Mycoplasma Pneumoniae infection and exacerbation of asthma, further molecular studies are required to establish the impact of Mycoplasma Pneumoniae on the onset and recurrence of asthma in different age groups.

Esposito et al.(20), klaritromycin treatment was given according to the PCR results in addition to standard treatment consisting of steroid and bronchodilator in a part of the wheezy patients. None of the patients in the group treated with clarithromycin during the 3 months follow-up period had a new wheeze. If clarithromycin treatment is not given in patients with acute C. Pneumoniae and / or M.
Pneumoniae infection, the wheezy cough is markedly overestimated.

Our research group consisted of infants and young children, and we assume that the API positivity rate is higher than the population. One explanation this may be because the unit we are working with is a 3rd stage health center in terms of our region, and that it is a center where patients are most recently referenced or directed.

M. Pneumoniae and C. Pneumoniae are atypical bacteria that have a very different life cycle and require T-helper 1 (Th-1) response to cleave both. The disease may appear subclinically in many of these infected patients, or both may cause acute infection of the respiratory tract. For this reason, the majority of the population has antibody against M. Pneumoniae and $C$. Pneumoniae $(28,29)$. Production of atypical bacteria in culture is difficult, so serological tests and PCR are more frequently used. In our study, we used both serologic tests (IgE and $\operatorname{IgM}$ antibody detection with micro ELISA) and PCR analysis to detect $M$. Pneumoniae and C. Pneumoniae infections and to achieve better results.

In recent years, many clinical trials have been performed in many adult and pediatric age ranges for both these atypical bacterial infections linked to the development of asthma or increased frequency of asthma attacks. However, there are similarities between the findings of these studies as well as in very conflicting results. The role of these atypical bacteria, which have an intracellular life cycle, in the pathogenesis of asthma is still unclear.

\section{Conclusions}

In our study, we could not statistically determine the effect of Mycoplasma Pneumoniae and Chlamydia Pneumoniae infections, which we expect to have on the API, a strong indicator of asthma development, in 0-2 year old infants with recurrent wheezing. However, when subgroup analysis was performed in wheeze children 0 2 years of age independently, the presence of Mycoplasma Pneumoniae and Chlamydia Pneumoniae was found to be statistically 
significant especially in the 1-2 years age range. In children with wheezing in the first and second years of life; the presence of these two microorganisms should be taken into consideration. We found that there was a statistically significant increase in the second year of life in both infectious agents and that these patients would develop recurrent wheezing episodes. In addition to classical acute bronchiolitis care in children with recurrent wheezing in this age group, we believe that long prospective trials with antibiotic medication such as clarithromycin should also be performed. In our study group, we detected the presence of $C$. Pneumoniae and M. Pneumoniae infections in patients at a lower rate than we expected. Possible reasons for this are the small age group of our study population and the technical insufficiency of the serology PCR methods we use. New studies using both larger populations and more systematic microbiological approaches are required to further understand the positive or negative impact of Mycoplasma Pneumoniae and Chlamydia Pneumoniae infections on the Asthma Predictive Index, a significant predictor that has been accepted as guidelines for the identification of asthma in children.

\section{REFERENCES}

1. Bacharier LB, Gulbert TW. Diagnosis anad management of early astma in preschool-aged children. J Allergy Clin Immunol. 2012; 130: 287-296

2. Camargo CA Jr, Rachelefsky G, Schatz M. Managing asthma exacerbations in the emergency department: summary of the National Asthma Education and Prevention Program Expert Panel Report 3 guidelines fort he management of asthma exacerbations. J. Allergy Clin Immunol. 2009; 124 (2 suppl): 5-14

3. Global Initiative for Asthma. Global strategy for asthma diagnosis and preventation (updated 2011) Available at: http/ /www.ginaasthma.org

4. Fitzgerald DA, Kilham HA. Bronchiolitis: assessment and evidence-based medicine. MJA 2004;180:399-404

5. Bialy L, Smith M, Bourke T, Becker L. The Cochrane Library and bronchiolitis: an umbrella review. Evid.Based Child Health I 2006:939-47.

6. Hammerschlag MR. Chlamydia pneumoniae. In: Berhman RE, Kliegman RM, Jenson HB Eds. Nelson Textbook of Pediadrics, 17th. Ed. Philadelphia: Saunders Co; 2004: 994-5.

7. The management of acute bronchitis in children. Douglas M F, Elliot A J. Expert Opin. Pharmacother. $2007: 84: 415-26$

8. Folkerts G, Busse WW, Nijkamp FP. Virus induced airway hyperresponsivenes and asthma. Am J Respir Crit Care Med 1998;157:1708-20

9. Atypical Pneumonia: Updates on Legionella, Chlamydophila, and Mycoplasma Pneumoniae. Sharma L, Losier A, Tolbert T, Dela Cruz CS, Marion CR. Clin Chest Med. 2017 ;381:45-58

10. Asner SA, Jaton K, Kyprianidou S, Nowak AM, Greub G. Chlamydia pneumoniae: possible association with asthma in children. Clin Infect Dis. 2014 ;58:8:1198-9

11. Kraft M, Cassell GH, Henson JE, Watson H, et al. Detection of Mycoplasma Pneumoniae in the airways of adult with chronic asthma. Am J Respir Crit Care Med 1998; 158: 998-100
12. Teoh L, Mackay IM, Van Asperen PP, Acworth JP et al. Presence of atopy increases the risk of asthma relapse. Arch Dis Child. 2017: 11. pii: archdischild2017-312982.

13. von Hertzen L, Vasankari T, Liippo K, Wahlström E et al. 3 Pneumonia and severity of asthma. Scand J Infect Dis 2002; 34: 22-27

14. Emre U, Roblin PM.Gelling $\mathrm{M}$ et al. The association of Chlamydia pneumoniae infection and reactive airway disease in children. Arch Pediatr Adolesc Med, 1994; 148: $121-25$

15. Cunningham A.F, Johnston SL, Julious SA, et al. Chronic Chlamydia pneumoniae infection and asthma exacerbations in children. Eur J Respir, 1998; 11: 34549.

16. Black PN, Scicchitano $\mathrm{R}$, Jenkins $\mathrm{CR}$, et al. Serological evidence of infection with Chlamydia pneumoniae is related to the severity of asthma. Eur $J$ Respir, 2000; 15: 254-59.

17. ten Brinke A, van Dissel JT, Sterk PJ, et al. Persistent airflow limitation in adult-onset nonatopic asthma is associated with serologic evidence of Chlamydia pneumoniae infection. J Allergy Clin Immunol, 2001; 107: 449-54.

18. Smith-Norowitz TA, K. Chotikanatis, D. P. Erstein, J.perlman, et al. Chlamydia pneumoniae enhances the Th2 profile of stimulated peripheral blood mononuclear cells from asthmatic patients. Human Immunology 2016:77: 382-88

19. Smith-Norowitz TA, Weaver D, Chorny V, Norowitz YM, et al. Chlamydia pneumoniae Induces Interferon Gamma Responses in Peripheral Blood Mononuclear Cells in Children with Allergic Asthma Scandinavian Journal of Immunology, 2017, 86, 59-64

20. Esposito, S., Blasi, F., Arosio, C., Importance of acute Mycoplasma pneumoniae and Chlamydia pneumoniae infections in children with wheezing. Eur J Respir, 2000; 16: 1142-1146. 
21. Biscardi S, Lorrot M, Marc E, Moulin F et al. Mycoplasma pneumoniae and Asthma in Children Clinical Infectious Diseases 2004; 38:1341-6

22. Bébéar C, Raherison C, Nacka F, de Barbeyrac B. Comparison of Mycoplasma pneumoniae Infections in asthmatic children versus asthmatic adults. Pediatr Infect Dis J. 2014 ; 33: 71-78.

23. Ozturk R. Toplumda Edinilmiş Pnomoni: Tanı yontemleri. In : Eraksoy $\mathrm{H}$, Yenen OŞ, eds. İnfeksiyon Hastalıkları ve Klinik Mikrobiyoloji 2000. Istanbul : Nobel Tip Kitapevleri 2000: 61-4.

24. Hardy RD, Jafri HS, Olsen K, et al. Mycoplasma pneumoniae induces chronic respiratory infection, airway hyperreactivity, and pulmonary inflammation: a murine model of infection associated chronic reactive airway disease. Infect Immun, 2002; 70; 649-54

25. Jeong YC, Yeo MS, Kim JH, Lee HB et al. Mycoplasma pneumoniae Infection Affects the Serum Levels of Vascular Endothelial Growth Factor and Interleukin-5 in Atopic Children. Allergy Asthma Immunol Res. 2012 ; 4: 92-97.

26. Kim J, Cho T, Moon J, Kim $\mathrm{C} R$ et al. Oh Serial Changes in Serum Eosinophil- associated Mediators between Atopic and Non-atopic Children after Mycoplasma pneumoniae pneumonia. Allergy Asthma Immunol Res. 2014 ; 6:428-33.

27. Wood PR, Kampschmidt JC, Dube PH, Cagle MP et al. Mycoplasma pneumoniae and health outcomes in children with asthma. Ann Allergy Asthma Immunol. 2017; 119:146-152.e2.

28. Daxboeck F, Krause R, Wenisch C. Laboratory diagnosis of Mycoplasma pneumoniae infection. Clin Microbiol Infect, 2003; 9: 263-273.

29. Stephens, RS. The cellular paradigm of chlamydial pathogenesis. Trends Microbiol, 2003; 11: 44-51.

@Copyright 2021 by Osmangazi Tıp Dergisi - Available online at tip.ogu.edu.tr @Telif Hakkı 2021 ESOGÜ Tıp Fakültesi - Makale metnine dergipark.org.tr/otd web sayfasından ulaşılabilir. 